\title{
RAPID DETECTION OF HUMAN TORQUE TENO VIRUSES USING HIGH-RESOLUTION MELTING ANALYSIS
}

\author{
Spandole $\mathrm{S}^{1 *}$, Cimponeriu $\mathrm{D}^{1}$, Toma $\mathrm{M}^{1}$, Radu $\mathrm{I}^{1}$, Ion $\mathrm{DA}^{2}$
}

\begin{abstract}
*Corresponding Author: Ms. Sonia Spandole (Ph.D. Student), Department of Genetics, University of Bucharest, Intrarea Portocalelor Street, No 1-3, 060101, Bucharest, Romania; Tel.: 004-0764-824-281, Fax: 004-0213-181565; E-mail: sonia.spandole@gmail.com
\end{abstract}

\section{ABSTRACT}

Torque teno viruses (TTVs) are recently discovered DNA viruses, with heterogeneous genomes, highly prevalent in populations worldwide. The species that infect humans are Torque teno virus (TTV), Torque teno midi virus (TTMDV) and Torque teno mini virus (TTMV). High-resolution melting analysis (HRMA) is a sensitive and effective method for genotyping and mutation scanning. Up to now, HRMA has not been utilized for detection of TTVs.

The aim of this study was to asses if HRMA is suitable for detecting TTVs variants. DNA was extracted from the blood and saliva of 13 healthy subjects for method optimization. Additionally, saliva samples from 100 healthy individuals were collected for estimating the TTVs' prevalence. Viral DNA was amplified by heminested polymerase chain reaction (PCR). Second round amplicons were used for the HRMA. The samples were analyzed using two fluorescent dyes, SYBR ${ }^{\circledR}$ Green I and EvaGreen ${ }^{\circledR}$.

The prevalence values for TTV, TTMDV and TTMV were $71.0,31.0$ and $54.0 \%$, respectively. The three major melting curve patterns corresponding to TTV, TTMDV and TTMV on HRMA can be easily distinguished regardless of kit used. Our results

\footnotetext{
${ }^{1}$ Department of Genetics, University of Bucharest, Bucharest, Romania

2 Department of Pathophysiology II, UMP “Carol Davila,” Bucharest, Romania
}

showed that HRMA is a rapid and efficient method of detecting human TTVs.

Keywords: Torque teno virus (TTV); Torque teno midi virus (TTMDV); Torque teno mini virus (TTMV); High-resolution melting analysis (HRMA).

\section{INTRODUCTION}

Torque teno viruses (TTVs) are small, non enveloped viruses, with an icosahedral capsid and a singlestranded circular DNA genome. One characteristic of TTVs is the extreme genomic heterogeneity that is highly uncommon for DNA viruses. Three virus species that infect humans have now been identified: TTV (Torque teno virus) [1], TTMV (Torque teno mini virus) [2] and TTMDV (Torque teno midi virus) [3]. Torque teno mini virus (2.8-2.9 kb) and TTMDV $(3.2 \mathrm{~kb})$ have smaller genomes than the TTV genome (3.75-3.9 kb). The TTV, TTMV and TTMDV each consist of a wide repertoire of isolates with genomewide sequence divergences of at least 50.0, 40.0 and $33.0 \%$, respectively [4]. Based on genomic heterogeneity, TTVs were separated into 39 genotypes and five major genetic groups [5,6], and it was suggested that these viruses may exist as a swarm of closely related but different viral species [7].

The sequence divergence is not evenly distributed throughout the genome. The untranslated region (UTR) is well conserved ( $73.0 \%$ nucleotide identity between the two highly divergent isolates TA278 
Table 1. Amplification conditions and primers [4] for heminested polymerase chain reaction.

\begin{tabular}{|l|c|c|c|}
\hline \multicolumn{4}{|c|}{ First Round of Polymerase Chain Reaction } \\
\hline & $90^{\circ} \mathrm{C}$ & $55^{\circ} \mathrm{C}$ & $72^{\circ} \mathrm{C}$ \\
\hline $1 \times{ }^{\mathrm{a}}$ & $10 \mathrm{~min}$. & & \\
\hline $1 \times$ & $2 \mathrm{~min}$. & & $30 \mathrm{sec}$. \\
\hline $2 \times$ & $2 \mathrm{~min}$. & $30 \mathrm{sec}$. & $30 \mathrm{sec}$. \\
\hline $35 \times$ & $35 \mathrm{sec}$. & $30 \mathrm{sec}$. & $1 \mathrm{~min}$. \\
\hline $1 \times$ & & & \\
\hline
\end{tabular}

\begin{tabular}{|l|c|c|c|}
\hline \multicolumn{4}{|c|}{ Second Round of Polymerase Chain Reaction } \\
\hline $1 \times^{\mathrm{a}}$ & $10 \mathrm{~min}$. & & \\
\hline $1 \times$ & $2 \mathrm{~min}$. & $30 \mathrm{sec}$. & $30 \mathrm{sec}$. \\
\hline $27 \times$ & $30 \mathrm{sec}$. & $30 \mathrm{sec}$. & $30 \mathrm{sec}$. \\
\hline $1 \times$ & & & $1 \mathrm{~min}$. \\
\hline
\end{tabular}

\begin{tabular}{|l|c|c|c|}
\hline \multicolumn{4}{|c|}{ Primers } \\
\hline Primer Code & PCR Round & Specificity & Forward of Reverse \\
\hline NG779 & first and second (TTV) & general & F \\
\hline NG780 & first and second (TTV) & general & F \\
\hline NG781 & first & general & R \\
\hline NG782 & first & general & R \\
\hline NG785 & second & TTV & R \\
\hline NG795 & second & TTMDV & F \\
\hline NG796 & second & TTMDV & R \\
\hline NG791 & second & TTMV & F \\
\hline NG792 & second & TTMV & F \\
\hline NG793 & second & TTMV & F \\
\hline NG794 & second & TTMV & R \\
\hline
\end{tabular}

a Additional step for hot-start enzymes (Immolate ${ }^{\mathrm{TM}}$ DNA polymerase, Bioline; and Dry PCR Master Mix, Bioron).

and SANBAN vs. $57.0 \%$ for the entire genome) and contains several highly con-served sequences (with more than $90.0 \%$ identity between isolates). In contrast, the translated region is characterized by a very high degree of diversity $[8,9]$.

The TTVs disease-causing potential is still under debate. Rocchi et al. [10] showed that certain variants pre-sent $\mathrm{CpG}$ motifs that are activators of proinflammatory cytokine production via toll-like receptor 9, and thus, may increase severity of inflammatory diseases. For the identi-fication of these variants, new methods for assessing the viral diversity are needed.

Polymerase chain reaction (PCR)-based methods were used to detect the presence of TTVs DNA in biological samples. The high TTVs sequence divergence and the particularities of PCR assay used for detection (primers, genomic region amplified, protocols) [11] may determine preferential amplification of some TTV genotypes and, thus, can influence the prevalence rates of TTVs presented in different articles.

One of the first diagnostic assays for TTVs was based on PCR that used primers derived from the N22 region of ORF1 [1]. This primer set did not amplify all TTV phylo-genetic groups. Subsequently, PCR techniques aimed for the conserved UTR, near the 5' end of ORF2 (Takahashi et al. [12]) or near the 3' end of ORF3 (Leary et al. [13]).

Methods based on analysis of changes in fluorescence intensity contribute to genome diversity analysis. One of these methods is high-resolution 

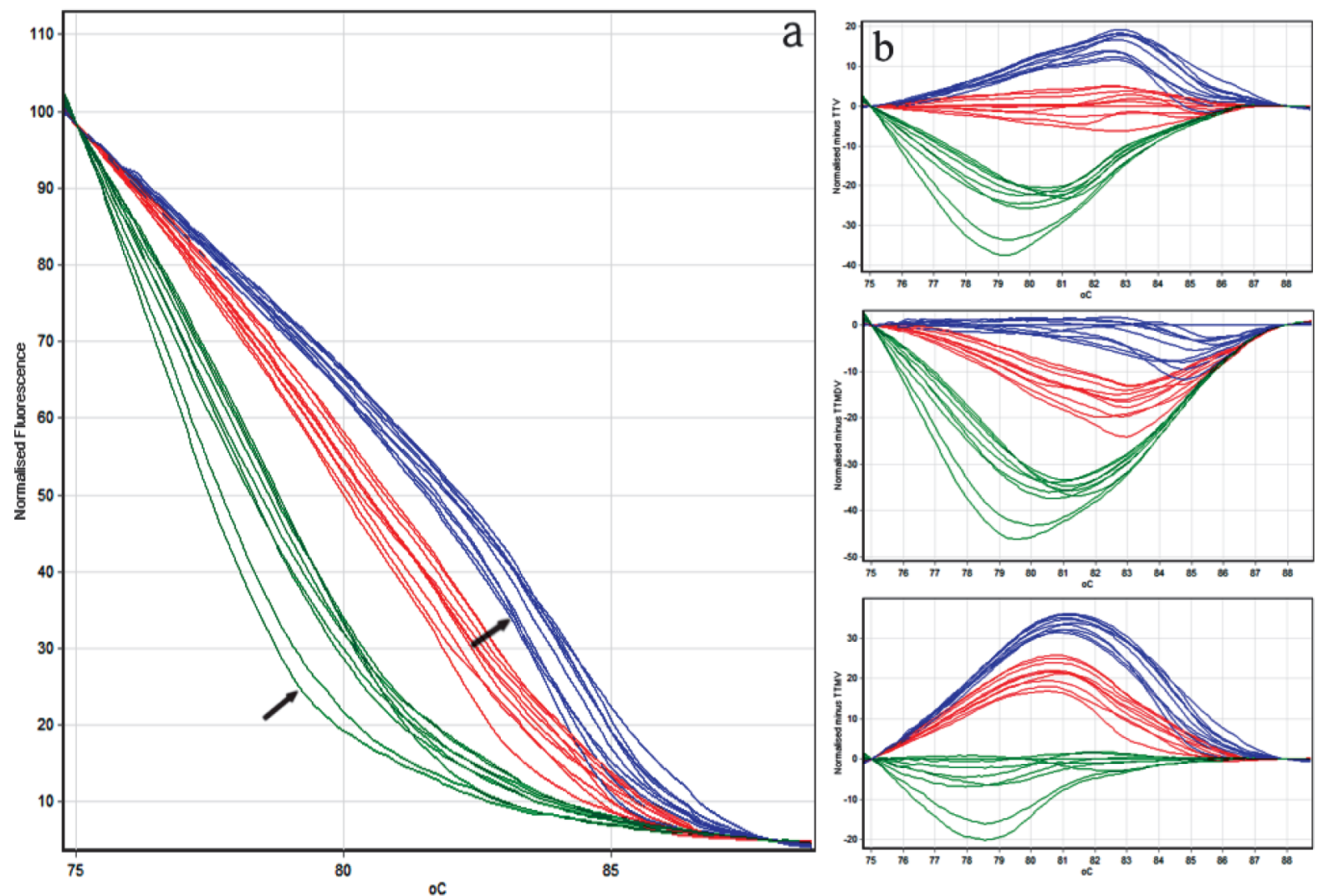

Figure 1. Different patterns of melting curves (a) and the difference graphs (b) for TTV (red), TTMDV (blue) and TTMV (green) in HRMA carried out with SensiMix ${ }^{\circledR}$ EvaGreen ${ }^{\circledR}$ fluorescent dye (Bioline).

melting analysis (HRMA) [14], which uses high datadensity acquisition during melting of amplicons in the presence of intercalating dye. Because of its low-cost, speed and simplicity, this method is used for genetic discrimination of various microorganisms, including viruses [15-18] and bacteria [19,20]. However, as far as we know, it has never been used for TTVs genotyping. The aim of this study was to assess if HRMA can be used for efficient and rapid detection of TTVs variants.

\section{MATERIALS AND METHODS}

Samples and DNA Extraction. A total of 113 healthy subjects from Bucharest, Romania, ranging in age from 19 to29 years, were selected for this study. Blood and saliva samples from 13 subjects were used for protocol optimization, whereas saliva samples ( $n=100)$ were used to estimate the TTVs prevalence. All subjects gave written informed consent to participate in this study according to the Helsinki
Declaration of 1975, as revised in 1983, concerning the ethical principles for medical research involving human subjects.

DNA was extracted from each blood sample using four different commercial kits (recommended for DNA extraction from eukaryotic cells): two spin-column-based protocols, AxyPrep ${ }^{\mathrm{TM}}$ Blood Genomic DNA Miniprep Kit (Axygen, Union City, CA, USA) and Ron's Blood DNA Mini Kit (Bioron, Ludwigshafen, Germany), and two pro-tocols without spin-column. Wizard ${ }^{\circledR}$ Genomic DNA Purification Kit (Promega, Madison, WI, USA), Pronto ${ }^{\circledR}$ DNA Extraction Kit (Pronto Diagnostics, Rehovot, Israel). The DNA was extracted according to the manufacturer's instructions from $250 \mu \mathrm{L}$ of blood. A one-tube purification method, OTP reagent (Bioron), was used for DNA extrac-tion from saliva.

Polymerase Chain Reaction. The detection of the three TTVs was realized using a two-step heminested-PCR protocol as described by Ninomiya et al. [4]. Each DNA sample was PCR amplified using 
Table 2. Torque teno virus genotyping results obtained with three DNA polymerases from blood and saliva DNA extracted with different commercial kits. (A: GoTaq ${ }^{\circledR}$ DNA Polymerase, Promega; B: Immolate ${ }^{\mathrm{TM}}$ DNA Polymerase, Bioline; C: Dry PCR Master Mix, Bioron)

\begin{tabular}{|c|c|c|c|c|c|c|c|c|c|c|c|c|c|c|c|}
\hline & \multicolumn{15}{|c|}{ DNA Extraction Kit } \\
\hline & \multicolumn{3}{|c|}{$\begin{array}{c}\text { AxyPrep }^{\mathrm{TM}} \text { Blood } \\
\text { Genomic DNA } \\
\text { Miniprep Kit }\end{array}$} & \multicolumn{3}{|c|}{$\begin{array}{c}\text { Ron's Blood } \\
\text { DNA Mini Kit }\end{array}$} & \multicolumn{3}{|c|}{$\begin{array}{c}\text { Wizard® Gnomic } \\
\text { DNA Purification } \\
\text { Kit }\end{array}$} & \multicolumn{3}{|c|}{$\begin{array}{l}\text { Pronto }{ }^{\circledR} \text { DNA } \\
\text { Extraction Kit }\end{array}$} & \multicolumn{3}{|c|}{$\begin{array}{l}\text { OTP Reagent } \\
\text { (saliva) }\end{array}$} \\
\hline & \multicolumn{15}{|c|}{ DNA Polymerase } \\
\hline$n$ & $\mathrm{~A}$ & $\mathrm{~B}$ & $\mathrm{C}$ & $\mathrm{A}$ & $\mathrm{B}$ & $\mathrm{C}$ & $\mathrm{A}$ & $\mathrm{B}$ & $\mathrm{C}$ & $\mathrm{A}$ & $\mathrm{B}$ & $\mathrm{C}$ & $\mathrm{A}$ & $\mathrm{B}$ & $\mathrm{C}$ \\
\hline 1 & {$[-]$} & {$[-]$} & {$[-]$} & {$[-]$} & {$[-]$} & {$[-]$} & {$[-]$} & {$[-]$} & {$[-]$} & {$[-]$} & {$[-]$} & {$[-]$} & {$[-]$} & {$[-]$} & {$[-]$} \\
\hline 2 & {$[+]$} & {$[+]$} & {$[+]^{\mathrm{a}}$} & {$[+]^{\mathrm{a}}$} & {$[+]$} & {$[+]^{\mathrm{a}}$} & {$[+]$} & {$[+]$} & {$[+]$} & {$[+]^{\mathrm{a}}$} & {$[+]^{\mathrm{a}}$} & {$[+]$} & {$[+]^{a}$} & {$[+]^{\mathrm{a}}$} & {$[+]^{\mathrm{a}}$} \\
\hline 3 & {$[+]$} & {$[+]^{\mathrm{a}}$} & {$[+]^{\mathrm{a}}$} & {$[+]^{\mathrm{a}}$} & {$[+]$} & {$[+]$} & {$[+]$} & {$[+]$} & {$[+]$} & {$[+]$} & {$[+]$} & {$[+]$} & {$[+]$} & {$[+]$} & {$[+]$} \\
\hline 4 & {$[+]^{\mathrm{a}}$} & {$[+]^{\mathrm{a}}$} & {$[+]$} & {$[+]$} & {$[+]$} & {$[+]$} & {$[+]$} & {$[+]$} & {$[+]$} & {$[+]$} & {$[+]$} & {$[+]$} & {$[+]$} & {$[+]$} & {$[+]$} \\
\hline 5 & {$[+]$} & {$[+]^{\mathrm{a}}$} & {$[+]$} & {$[+]$} & {$[+]^{\mathrm{a}}$} & {$[+]$} & {$[+]$} & {$[+]$} & {$[+]$} & {$[+]$} & {$[+]^{\mathrm{a}}$} & {$[+]$} & {$[+]$} & {$[+]$} & {$[+]$} \\
\hline 6 & {$[+]$} & {$[+]^{\mathrm{a}}$} & {$[+]$} & {$[+]$} & {$[+]$} & {$[+]$} & {$[+]$} & {$[+]$} & {$[+]$} & {$[+]$} & {$[+]$} & {$[+]$} & {$[+]$} & {$[+]$} & {$[+]^{\mathrm{a}}$} \\
\hline 7 & {$[+]$} & {$[+]^{\mathrm{a}}$} & {$[+]$} & {$[+]$} & {$[+]$} & {$[+]$} & {$[+]$} & {$[+]$} & {$[+]$} & {$[+]$} & {$[+]$} & {$[+]$} & {$[+]$} & {$[+]$} & {$[+]$} \\
\hline 8 & {$[-]$} & {$[-]$} & {$[-]$} & {$[-]$} & {$[-]$} & {$[-]$} & {$[-]$} & {$[-]$} & {$[-]$} & {$[-]$} & {$[-]$} & {$[-]$} & {$[-]$} & {$[-]$} & {$[-]$} \\
\hline 9 & {$[+]^{\mathrm{a}}$} & {$[+]$} & {$[+]$} & {$[+]$} & {$[+]$} & {$[+]$} & {$[+]$} & {$[+]$} & {$[+]$} & {$[+]$} & {$[+]^{\mathrm{a}}$} & {$[+]$} & {$[+]$} & {$[+]$} & {$[+]^{\mathrm{a}}$} \\
\hline 10 & {$[+]$} & {$[+]$} & {$[+]$} & {$[+]$} & {$[+]$} & {$[+]$} & {$[+]$} & {$[+]$} & {$[+]$} & {$[+]$} & {$[+]$} & {$[+]$} & {$[+]$} & {$[+]$} & {$[+]^{\mathrm{a}}$} \\
\hline 11 & {$[+]$} & {$[+]$} & {$[+]$} & {$[+]$} & {$[+]$} & {$[+]$} & {$[+]$} & {$[+]$} & {$[+]$} & {$[+]$} & {$[+]$} & {$[+]$} & {$[+]$} & {$[+]$} & {$[+]^{\mathrm{a}}$} \\
\hline 12 & {$[+]$} & {$[+]^{\mathrm{a}}$} & {$[+]$} & {$[+]$} & {$[+]$} & {$[+]$} & {$[+]$} & {$[+]$} & {$[+]$} & {$[+]$} & {$[+]$} & {$[+]$} & {$[+]$} & {$[+]^{\mathrm{a}}$} & {$[+]$} \\
\hline 13 & {$[+]$} & {$[+]$} & {$[+]$} & {$[+]$} & {$[+]$} & {$[+]$} & {$[+]$} & {$[+]$} & {$[+]$} & {$[+]$} & {$[+]$} & {$[+]$} & {$[+]$} & {$[+]^{\mathrm{a}}$} & {$[+]$} \\
\hline
\end{tabular}

${ }^{a}$ Indicates a weaker signal in agarose gel.

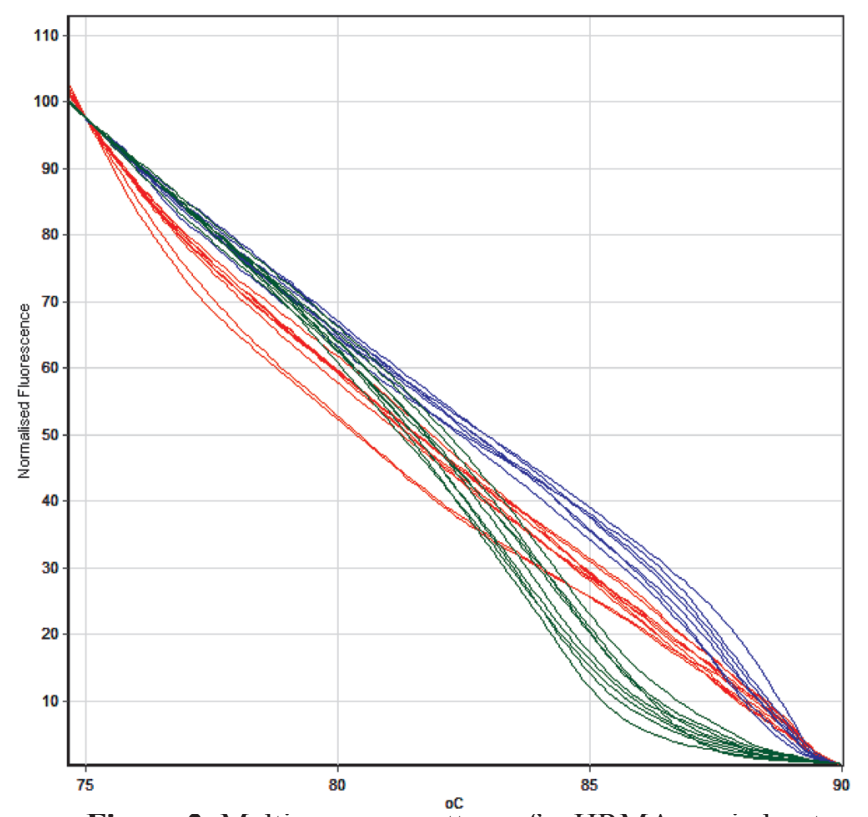

Figure 2. Melting curve patterns for HRMA carried out using SYBR Green Master Mix (Invitek).

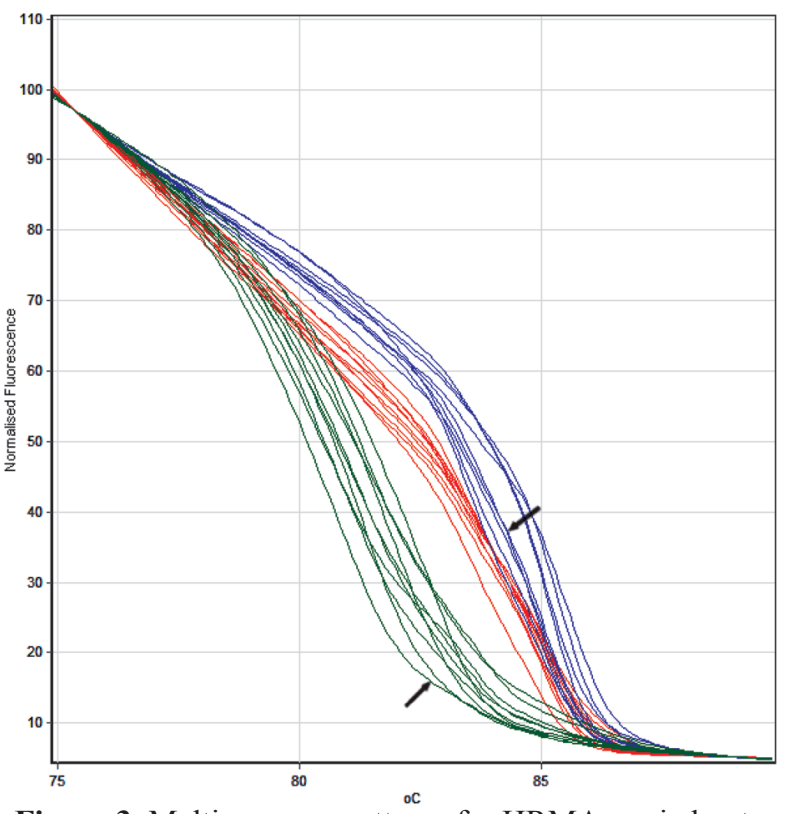

Figure 3. Melting curve patterns for HRMA carried out using Maxima ${ }^{\circledR}$ SYBR Green qPCR (Fermentas). 
Table 3. Amplicon properties for five isolates of the torque teno virus, torque teno midi virus and torque teno mini virus.

\begin{tabular}{|l|c|c|c|}
\hline \multicolumn{1}{|c|}{ Isolate } & $\begin{array}{c}\text { Length } \\
\text { (bp) }\end{array}$ & \%GC & $\mathbf{T}_{\mathbf{m}}$ \\
\hline \multicolumn{4}{|c|}{ Torque Teno Virus } \\
\hline TA278 & 114 & 63 & 85 \\
\hline JA9 & 114 & 63 & 85 \\
\hline JA1 & 114 & 65 & 86 \\
\hline JA4 & 114 & 65 & 86 \\
\hline JA20 & 114 & 66 & 86 \\
\hline
\end{tabular}

\begin{tabular}{|l|c|c|c|}
\hline \multicolumn{4}{|c|}{ Torque Teno Midi Virus } \\
\hline MDJHem2 & 88 & 67 & 85 \\
\hline SAV2 & 88 & 68 & 85 \\
\hline MD2-032 & 88 & 69 & 86 \\
\hline MD1-073 & 88 & 70 & 86 \\
\hline SAV1 & 88 & 70 & 86 \\
\hline
\end{tabular}

\begin{tabular}{|l|c|c|c|}
\hline \multicolumn{4}{|c|}{ Torque Teno Mini Virus } \\
\hline CBD203 & 70 & 54 & 77 \\
\hline CLC062 & 72 & 58 & 79 \\
\hline CBD279 & 72 & 60 & 80 \\
\hline CBD231 & 72 & 61 & 80 \\
\hline CLC138 & 72 & 61 & 81 \\
\hline
\end{tabular}

three DNA-polymerases: GoTaq ${ }^{\circledR}$ DNA Polymerase (Promega), Immolase ${ }^{\mathrm{TM}}$ DNA Polymerase (Bioline, Luckenwalde, Germany), and Dry PCR Master Mix (blue-stain) (Bioron).

For the first step, the amplification reaction was car-ried out in a total volume of $15 \mu \mathrm{L}$ containing $1 \times$ PCR buffer solution, $1.5 \mathrm{mmol} / \mathrm{L} \mathrm{MgCl}_{2}, 100 \mu \mathrm{mol} / \mathrm{L}$ dNTP mix, $0.5 \mu \mathrm{mol} / \mathrm{L}$ of each primer, 0.6 units of DNA-polymerase and $1.5 \mu \mathrm{L}$ of genomic DNA ex- tract. The second step consisted of three different reactions for the specific amplification of the viral species. For the second step, $1 \mu \mathrm{L}$ of amplicon from the first round of PCR was used as a template. The amplification programs and primers can be found in Table 1. The amplicons of the second PCR were resolved by $2.0 \%(\mathrm{w} / \mathrm{v})$ agarose gel and were electropho-resed at $5 \mathrm{~V} / \mathrm{cm}$ for $20 \mathrm{~min}$. The gel was visualized under UV light after ethidium bromide staining.

High-Resolution Melting Analysis. The samples co-infected with all three TTVs were further analyzed by HRMA using three commercial kits and two different fluorescent dyes: SensiMix ${ }^{\circledR}$ with EvaGreen ${ }^{\circledR}$ (Bioline), Invitek SYBR Green Master Mix (Invitek, Berlin, Germany) and Maxima ${ }^{\circledR}$ SYBR Green qPCR (Fermentas, Glen Burnie, MD, USA). The amplification reaction was carried out in a total volume of $20 \mu \mathrm{L}$ and used $2 \mu \mathrm{L}$ of second-round amplicons as template DNA. High-resolution melting analysis was performed in a Rotor-Gene 6000 series instrument (Corbett Research, Sydney, NSW, Australia) using software version 1.7.

Melting curves were generated by increasing the tem-perature from $65^{\circ} \mathrm{C}$ to $90^{\circ} \mathrm{C}$ ramping by 0.1 degrees per step, with a gap of 2 seconds between steps. For the HRMA normalization regions of 75$77^{\circ} \mathrm{C}$ and $88-90^{\circ} \mathrm{C}$ were applied.

\section{RESULTS}

The prevalence of TTV, TTMDV and TTMV in saliva samples was $71.0,31.0$ and $54.0 \%$, respectively. There were no qualitative differences in the genotyping results obtained for the same sample extracted with four commercial kits and amplified with three different DNA polymerases. The distribution of TTVs did not differ in blood and saliva samples (Table 2).

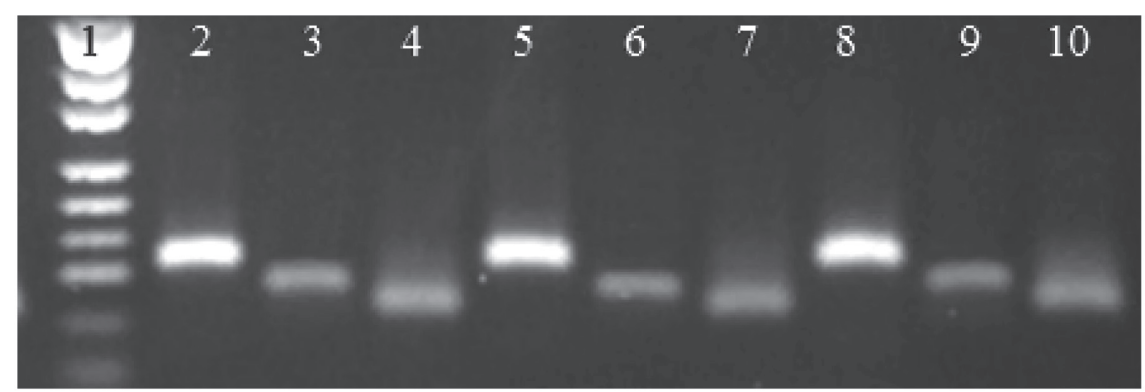

Figure 4. The HRM amplicons electrophoresed in 2.0\% (w/v) agarose gel stained with ethidiumbromide.Lanes 2,5 and8:TTV; lanes3,6and9:TTMDV; lanes4,7 and 10:TTMV; lane 1: pUC19 DNA/MspI (HpaII) marker (Fermentas). 
Ten samples with triple coinfection were selected for the HRMA using SensiMix ${ }^{\circledR}$, SYBR Green Master Mix and Maxima ${ }^{\circledR}$ SYBR Green $q P C R$ commercial kits (Figure 1a, Figure 2 and Figure 3). Prior to HRMA, amplicons were verified by gel electrophoresis (Figure 4).

The three major melting curve patterns corresponding to TTV, TTMDV and TTMV can be easily distinguished regardless of the kit used, although they present slightly different aspects. The melting curve patterns were similar when samples were retested under the same conditions.

\section{DISCUSSION}

Torque teno viruses have several characteristics (e.g., genomic heterogeneity, great number of isolates, high prevalence) that play an important role in the way their analysis must be approached. A wide range of TTV prevalence has been described worldwide. Depending on the identification method used, TTV prevalence may vary from $46.0-62.0 \%$ in Brazil $[21,22]$ to $94.0 \%$ in Russia [23]. For TTMV, prevalence ranges between $48.0 \%$ in Norway [24] and $67.0-72.0 \%$ in Brazil [21,22], and TTMDV occurs in at least $40.0 \%$ of the general population [25]. Our results are in accordance with prevalence values reported for TTVs in other populations, except for TTMDV, which has a lower prevalence in subjects selected for this study (31.0\%).

Analyzing such heterogeneous genomes represents a challenge. The high sequence variation of the genomes, along with high percentage of cytosine and guanine, make primer design difficult. The heminested PCR assay designed by Ninomiya et al. [4] amplifies at least 49 TTV isolates, 20 TTMDV isolates, and 13 TTMV isolates.

The 10 melting curve patterns on the HRMA suggest that different viral isolates may be present in our cohort, or individuals may be coinfected with several isolates. These may explain the shift of the melting curve for TTMDV and TTMV samples marked in Figure 1 and Figure 3.

The melting curve aspect is influenced by the length, percentage of cytosine and guanine (\%GC) and melting point $\left(\mathrm{T}_{\mathrm{m}}\right)$ of the amplification products. The $\% \mathrm{GC}$ and $\mathrm{T}_{\mathrm{m}}$ were calculated in silico for amplicons produced by five isolates of each virus (Table 2 ).

The differences between TTV and TTMDV amplicons are minimal, and an accurate discrimination is difficult. Moreover, we have run a folding simulation for each of the amplicons using Quickfold [26] at $65^{\circ} \mathrm{C}$ (the temperature in the beginning of HRMA) and observed that each amplicon forms slightly different secondary structures when denatured. This influences the melting curve pattern. Subsequent to HRMA, the resulting amplicons were verified by gel electrophoresis and no differences were observed (Figure 4).

Another component of the HRMA that influences the curve patterns is the fluorescent dye. There are various types of double-stranded DNA (dsDNA) intercalating dyes with different properties. For HRMA, the dye must provide detailed information on the melting behavior of an amplified target. Ideally, the dye should not bind preferentially to pyrimidines or purines, change the $T_{m}$ of the amplicon, or inhibit DNA amplification.

There are two main types of dyes: saturating and non saturating dyes. SYBR ${ }^{\circledR}$ Green I is a non saturating dsDNA intercalating dye and is not usually recommended for high-resolution melt applications because at high concentrations, SYBR ${ }^{\circledR}$ Green I inhibits the DNA polymerase. At low concentrations $\mathrm{SYBR} \otimes$ Green $\mathrm{I}$ is able to redistribute from the melted regions back to the regions of dsDNA, which results in poor base-difference discrimination [27].

EvaGreen ${ }^{\circledR}$ is a special kind of saturating dye, so - called "release-on-demand." For this dye, the fluorescence is quenched when unbound to DNA, this allows the use of non saturating dye concentrations, thus ensuring no PCR inhibition. EvaGreen ${ }^{\circledR}$ improves the resolution and accuracy of HRMA by increased fluorescence and lack of redistribution during melting [28]. Farrar et al. [29] showed that EvaGreen $₫$ is more suitable than SYBR $®$ Green I for HRMA.

Our results show that the best discrimination is obtained using EvaGreen ${ }^{\circledR}$ (Figure 1 vs. Figures 2 and 3). The differences between the curve patterns obtained with SYBR ${ }^{\circledR}$ Green I may be due to the DNA-polymerase activity [SYBR Green Master Mix (Figure 2) vs. Maxima ${ }^{\circledR}$ SYBR Green qPCR (Figure 3)] and/or dye concentration in the master mixes used for this study.

As with any technique, HRMA analysis has its limitations. Fluorescent dyes used in HRMA lack sequence specificity and can bind to any dsDNA, including non targets such as primer dimmers and non specific products, which will bias the results of melting analysis [28]. In addition, all the PCR com- 
ponents are present at the time of melting analysis and may have a great impact on the melting curve shape and position [30].

The amplicons corresponding to TTV, TTMDV, and TTMV obtained in the assay we used have different lengths (Table 3). The \%GC and also GC distribution in relation to the ends/center of amplicons differ due to genomic heterogeneity. These aspects influence the melting curves' aspect as well.

Despite these limitations, HRMA is a sensitive method and provides more information on the amplification products, such as sequence-dependent shape of the melting curve and $\mathrm{T}_{\mathrm{m}}$, enabling discrimination of products with same length but different sequence [31].

Our results showed that HRMA is a rapid method of detecting human TTVs (HRMA takes approximately $20 \mathrm{~min}$. after second round amplicons are obtained) compared to the classical PCR-electrophoresis method, which is more time-consuming (gel preparation, running and staining). High-resolution melting analysis provides additional information regarding amplification products $\left(\mathrm{T}_{\mathrm{m}}\right.$, melting curve shape) compared to classic PCR methods followed by gel electrophoresis, which indicate only the presence or absence of the target sequence.

In conclusion, due to the advantages of this technique, HRMA is a rapid and accurate method for detecting TTVs. Developing new and more sensitive HRMA assays may lead to easy and accurate detection of TTV isolates.

\section{ACKNOWLEDGMENTS}

This study was financially supported by research project PN II 42-161/2008 and by the Sectoral Operational Programme Human Resources Development, financed from the European Social Fund and by the Romanian Government under contract number POSDRU/89/1.5/S/ 64109 and by the Romanian Ministry of Education and Research.

\section{REFERENCES}

1. Nishizawa T, Okamoto H, Konishi K, Yoshizawa H, Miyakawa Y, Mayumi M. A novel DNA virus (TTV) associated with elevated transaminase levels in posttransfusion hepatitis of unknown etiology. Biochem Biophys Res Commun. 1997; 241(1): 92-97.
2. Takahashi K, Hijikata M, Samokhvalov EI, Mishiro S. Full or near full length nucleotide sequences of TT virus variants (Types SANBAN and YONBAN) and the TT virus-like mini virus. Intervirology. 2000; 43(2): 119-123.

3. Ninomiya $M$, Nishizawa $T$, Takahashi $M$, Lorenzo FR, Shimosegawa T, Okamoto H. Identification and genomic characterization of a novel human torque teno virus of $3.2 \mathrm{~kb}$. J Gen Virol. 2007; 88(Pt 7): 1939-1944.

4. Ninomiya $M$, Takahashi $M$, Nishizawa $T$, Shimose-gawa T, Okamoto H. Development of PCR assays with nested primers specific for differential detection of three human anelloviruses and early acquisition of dual or triple infection during infancy. J Clin Microbiol. 2008; 46(2): 507-514.

5. Okamoto H, Nishizawa T, Ukita M, Takahashi M, Fukuda M, Iizuka $\mathrm{H}$, et al. The entire nucleotide sequence of a TT virus isolate from the United States (TUS01): comparison with reported isolates and phylogenetic analysis. Virology. 1999; 259(2): 437-448.

6. Biagini $\mathrm{P}$, Todd $\mathrm{D}$, Bendinelli $\mathrm{M}$, Hino $\mathrm{S}$, Mankertz A, Mishiro S, et al. Anellovirus in virus taxonomy. In: Fauquet CM, Mayo MA, Maniloff J, Desselberger U, Ball LA, Eds. Eighth Report of the International Committee on Taxonomy of Viruses. London: Elsevier/Academic Press. 2004: 335-341.

7. Khudyakov YE, Cong ME, Nichols B, Reed D, Dou XG, Viazov SO, et al. Sequence heterogeneity of TT virus and closely related viruses. J Virol. 2000; 74(7): 2990-3000.

8. Hijikata M, Takahashi K, Mishiro S. Complete circular DNA genome of a TT virus variant (isolate name SANBAN) and 44 partial ORF2 sequences implicating a great degree of diversity beyond genotypes. Virology. 1999; 260(1): 17-22.

9. Erker JC, Leary TP, Desai SM, Chalmers ML, Mushahwar IK. Analyses of TT virus full-length genomic sequences. J Gen Virol. 1999; 80(Pt 7): 1743-1750.

10. Rocchi J, Ricci V, Albani M, Lanini L, Andreoli E, Macera L, et al. Torquetenovirus DNA drives proinflammatory cytokines production and secretion by immune cells via toll-like receptor 9 . Virology. 2009; 394(2): 235-242. 
11. Devalle S, Niel C. A multiplex PCR assay able to simultaneously detect Torque teno virus isolates from phylogenetic groups 1 to 5 . Braz J Med Biol Res. 2005; 38(6): 853-860.

12. Takahashi K, Hoshino H, Ohta Y, Yoshida N, Mishiro S. Very high prevalence of TT virus (TTV) infection in general population of Japan revealed by a new set of PCR primers. Hepatol Res. 1998; 12(3): 233-239.

13. Leary TP, Erker JC, Chalmers ML, Desai SM, Mushahwar IK. Optimized PCR assay for the detection of TT virus. J Virol Meth. 1999; 82(2): 109-112.

14. Wittwer CT, Reed GH, Gundry CN, Vandersteen JG, Pryor RJ. High-resolution genotyping by amplicon melting analysis using LCGreen. Clin Chem. 2003; 49(6 Pt 1): 853-860.

15. Toi CS, Dwyer DE. Prevalence of varicella-zoster virus genotypes in Australia characterized by highresolution melt analysis and ORF22 gene analyses. J Med Microbiol. 2010; 59(Pt 8): 935-940.

16. Matsuda Y, Qazi Y, Iwaki Y. A rapid and efficient method BK polyomavirus genotyping by highresolution melting analysis. J Med Virol. 2011; 83(12): 2128-2134.

17. Steer PA, O'Rourke D, Ghorashi SA, Noormohammadi AH. Application of high-resolution melting curve analysis for typing of fowl adenoviruses in field cases of inclusion body hepatitis. Aust Vet J. 2011; 89(5): 184-192.

18. Zhao XT, Zhou DQ, Wu S, Chen YW, Shao Y, Zhang J, et al. Genotyping cytomegalovirus UL97 muta-tions by high-resolution melting analysis with unlabeled probe. Arch Virol. 2012; 157(3): 475-481.

19. Robertson T, Bibby S, O'Rourke D, Belfiore T, Lambie H, Noormohammadi A. Characterization of Chlamydiaceae species using PCR and high resolution melt curve analysis of the $16 \mathrm{~S}$ rRNA gene. J Appl Microbiol. 2009; 107(6): 2017-2028.

20. Li JH, Yin YP, Zheng HP, Zhong MY, Peng RR, Wang B, et al. A high-resolution melting analysis for genotyping urogenital Chlamydia trachomatis. Diagn Microbiol Infect Dis. 2010; 68(4): 366-374.

21. Devalle S, Niel C. Distribution of TT virus genomic groups 1-5 in Brazilian blood donors,
HBV car-riers, and HIV-1-infected patients. J Med Virol. 2004; 72(1): 166-173.

22. Niel C, de Oliveira JM, Ross RS, Gomes SA, Roggendorf M, Viazov S. High prevalence of TT virus infection in Brazilian blood donors. J Med Virol. 1999; 57(3): 259-263.

23. Vasilyev EV, Trofimov DY, Tonevitsky AG, Ilinsky VV, Korostin DO, Rebrikov DV. Torque Teno Virus (TTV) distribution in healthy Russian population. Virol J. 2009; 6(9): 134-138.

24. Moen EM, Huang L, Grinde B. Molecular epidemiology of TTV-like mini virus in Norway. Arch Virol. 2002; 147(1): 181-185.

25. Ninomiya M, Takahashi M, Shimosegawa $T$, Okamoto H. Analysis of the entire genomes of fifteen torque teno midi virus variants classifiable into a third group of genus Anellovirus. Arch Virol. 2007; 152(11): 1961-1975.

26. Markham NR, Zuker M. DINAMelt web server for nucleic acid melting prediction. Nucleic Acids Res. 2005; 33(Web server issue): W577-W581.

27. Introduction to High Resolution Melt Analysis (http://www.kapabiosystems.com/public/pdfs/ kapa-hrm-fast-pcr-kits/Introduction_to_High_ Resolution_Melt_Analysis_Guide.pdf; accessed June 11 2012).

28. Ruskova L, Raclavsky V. The potential of high resolution melting analysis (hrma) to streamline, facilitate and enrich routine diagnostics in medical microbiology. Biomed Pap Med Fac Univ Palacky Olomouc Czech Repub. 2011; 155(3): 239-252.

29. Farrar JS, Reed GH, Wittwer CT. High-resolution melting curve analysis for molecular diagnostics. In: Patrinos GP, Ansorge W, Eds. Molecular Diagnostics, 2nd ed. Amsterdam; Boston: Elsevier/Academic Press. 2010: 229-245.

30. Ririe KM, Rasmussen RP, Wittwer CT. Product differentiation by analysis of DNA melting curves during the polymerase chain reaction. Anal Biochem.1997; 245(2): 154-160.

31. Herrmann MG, Durtschi JD, Wittwer CT, Voelkerding KV. Expanded instrument comparison of amplicon DNA melting analysis for mutation scanning and genotyping. Clin Chem. 2007; 53(8): 1544-1548. 